\title{
APPLICATION OF THE EU EXPERIENCE OF THE FINANCIAL SYSTEMS' TRANSFORMATION IN THE CONTEXT OF THE DEBT CRISIS FOR UKRAINE
}

\author{
Maryna Shuba \\ PhD (Economics), Associate Professor \\ V. N. Karazin Kharkiv National University \\ 4, Svobody sq., Kharkiv, Ukraine, 61022 \\ e-mail: marinashuba@karazin.ua \\ ORCID: orcid.org/0000-0003-2581-6914 \\ Iryna Derid \\ $\mathrm{PhD}$ (Economics), Associate Professor \\ V. N. Karazin Kharkiv National University \\ 4, Svobody sq., Kharkiv, Ukraine, 61022 \\ e-mail: i.a.derid@karazin.ua \\ ORCID: orcid.org/0000-0002-1593-3132 \\ Olena Khanova \\ PhD (Geography), Associate Professor \\ V. N. Karazin Kharkiv National University \\ 4, Svobody sq., Kharkiv, Ukraine, 61022 \\ e-mail: e.v.khanova@karazin.ua \\ ORCID: orcid.org/0000-0002-0681-4860 \\ Kateryna Makarchuk \\ $\mathrm{PhD}$ (Economics), Associate Professor \\ V. N. Karazin Kharkiv National University \\ 4, Svobody sq., Kharkiv, Ukraine, 61022 \\ e-mail: k.makarchuk.@karazin.ua \\ ORCID: orcid.org/0000-0002-7712-3071
}

\begin{abstract}
Transformation of financial systems is an extremely important process because the stability of the world economy depends on their adequacy, balance and efficiency. The financial systems of the EU countries have undergone a number of transformations, during which new mechanisms to strengthen economic governance were created. However, not all problems have been solved yet. The debt crisis has revealed existing weaknesses in the structure, thus provoking the need to strengthen the financial architecture by solving existing problems, while identifying and preventing possible future threats. The subject of research of the article is main directions of the transformation of the European financial system in the context of the debt crisis. The goal is to summarize the EU financial systems' main directions of transformation in the context of the debt crisis and to identify the possibilities of their application for Ukraine. General scientific methods are used, such as system analysis which allowed to collect and systemize statistical data on EU countries and Ukraine for further analysis, correlation analysis and trend analysis, which allowed to determine the cumulative effect of unsecured bank loans and long-term government bonds yields of the EU countries and Ukraine on the level of their public debt. The following results were obtained: correlation analysis show the existence of correlation between unsecured bank loans and long-term government bonds yields of the EU countries and Ukraine with the level of their public debt. Conclusions: there are quite a lot of possibilities of application of the EU experience of the financial systems' transformation for Ukraine. One of the basic is introduction of annual banks stress testing; further convergence of banking sector regulation to the requirements of Basel 3 and implementation of LCR; initiation of the process of creating a single mega regulator of the financial market.
\end{abstract}

Keywords: financial system; transformation; debt, debt crisis.

\section{Introduction.}

The debt crisis in the euro area has highlighted the need for a more stable EU financial system. The current stage of transformation of the financial systems of the EU countries provides for the emergence of new supranational institutions, as well as a change in the old ones that operated on the previous stages. New mechanisms have been created to strengthen economic governance through sustainable monitoring of fiscal and economic policies and restoring public confidence in the financial system. However, there still appears to be a number of problems. Mechanisms should be reviewed regularly to ensure that they meet current realities, and confirm that they actually achieve tasks for which they were established while simultaneously they should be applied on an even basis in all member states to ensure equal conditions.

The formation of the basis of post-crisis development of the Ukrainian financial system needs to be implemented, taking into account the global financial and institutional transformations, especially the transformation of the EU countries' financial systems, and the prospects for the European integration of our state, which will result, firstly, in the liberalization of Ukrainian market, secondly, in the need to join European systems of regulation and supervision of financial markets. Today, Ukraine is actively using the experience of EU countries in the transformation of the financial system. However, it is 
necessary to take into account the differences in the economic development of EU countries and Ukraine and to adapt the European experience to Ukrainian realities. So the study is of both scientific and practical interest.

\section{Literature review.}

The writings of many scientists are dedicated to the study of the EU financial system transformation. Basically, they can be divided into three groups: the first is comprised of the pre-crisis period papers, the second consists of the writings that explore specific aspects of the financial system transformation in the EU countries and do not consider these issues as a whole, the third group includes systemic research of the financial systems transformation in the EU countries in response to the debt crisis. To the first group we can include the research Allen et al. [1], in which the authors examine the financial systems development of all member states, the changes that have occurred, and compare the old members with the new ones after the enlargement of the EU in 2004. Among the publications, the ECB collected works Transformation of the European Financial System Conference [4] and the paper of P. Mooslechner [16] should be noted. The writings examine in detail the changes in the financial systems of the EU countries that took place during the pre-crisis period, and further prospects for transformation.

As for the second group of studies, great attention is paid to identifying prospects for the reformation of the banking system $[11 ; 12 ; 14 ; 19]$. Also today, there are many studies on the impact of Brexit on the EU financial market $[2 ; 8 ; 17]$.

We believe that there is not much research of the third group. Among them, we should highlight the research by J. Kundera [9], which examines the institutional reforms of the EU financial system, which should make it more stable. The Summary of the 44th OeNB Economics Conference on the topic "The Financial System of the Future" systematizes the views of researchers on the feasibility of ongoing reforms and directions for the future transformation of the EU financial systems [18].

Nowadays, in our opinion, insufficient attention is paid not to the study of individual aspects of the financial systems transformation in EU countries but to the study in general. In addition, given the European direction chosen by Ukraine, we consider it necessary to determine what measures of reformation of the EU financial system should be carried out in our country.

The aim and objectives of the study. The scientific objective of this paper is to summarize the EU financial systems' main directions of transformation in the context of the debt crisis and to identify the possibilities of their application for Ukraine.

Research methodology. We used the hypothesis about the interrelation between the components of the country's financial system in the context of its transformation, which covers the time period from 2007 to 2017 . System analysis was used in the study, which allowed to collect and systemize statistical data on EU countries and Ukraine for further analysis; trend analysis and its results helped to determine the growth or decline trends of the key components of Ukrainian financial systems and the EU countries; the correlation analysis and its results helped to substantiate the impact of the state budget revenue on such indicators of the country's financial system as government expenditures, government budget surplus, public debt, as well as the cumulative effect of the ratio of unsecured bank loans and long-term government bond yields on countries public debt. However, as to the promising areas of research, it should be noted that this methodology does not take into account the identification of factor loadings and does not allow us to determine which component of the financial system of the studied countries is the most significant from the point of view of the national financial system development prospects. To this end, we suggest carrying out factor analysis once more in the further research.

Results. Measures, aimed to transform the national financial systems of the EU countries began when the debt crisis became a threat to the existence of the union itself. According to the Maastricht Treaty, the ratio of the state deficit to the gross domestic product should not exceed 3\%. However, for example, only Denmark, Estonia, Luxembourg, Finland and Sweden retained this standard in 2009.

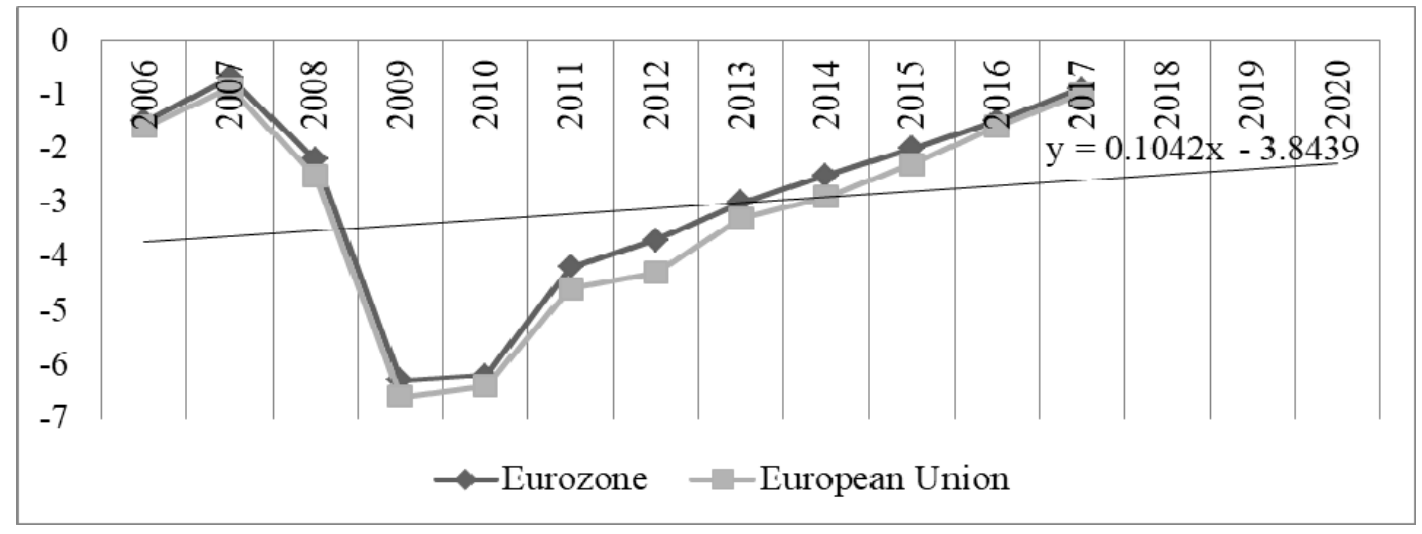

Fig. 1. Government deficit ( $\%$ of GDP) [6]

In Figure 1 it can be seen that the state deficit in the EU and Eurozone in 2009-2010 exceeded the Maastricht Treaty of $3 \%$ more than twice. Thus, the 24 state deficit of the Eurozone was $6.3 \%$ and $6.2 \%$ respectively, while in the EU it was $6.6 \%$ and $6.4 \%$ respectively. 
Another criterion for the Maastricht Treaty, which was not followed by most EU countries, is the ratio of public debt to GDP, which should not exceed $60 \%$ of GDP in European countries (Figure 2). This criterion was also violated in pre-crisis years, but since 2008, the growth of public debt in general in the EU has taken a threatening nature. Of course, over time, this led to an increase in profitability of government bonds, which had to compensate investment risks by increasing profitability. In turn, this had led to an increase of public debt.

The difference in the EU debt crisis from other regional debt crises is that most countries have a common currency, so the spread of negative impacts of the debt crisis of the PIIGS countries to other European Union countries is more rapid and significant. Therefore, it seems advisable to consider the impact of the level of unsecured bank loans and the profitability of long-term government bonds on public debt of the EU countries, whose financial systems were most vulnerable to crises in the world economy, the so-called PIIGS countries (which include Portugal, Italy, Ireland, Greece and Spain), and those countries which are considered to be locomotives of the EU - Germany and France. Also, in the framework of our study, it is worthwhile to conduct similar calculations for Ukraine.

In some EU countries, there has been an increase in the volume of loans with high risk, that is, unsecured loans. Almost all PIIGS countries have a rather high level of bad loans (Figure 3). It is particularly high in Greece - 45.6\% in 2017. Only Spain has a moderate level of unsecured loans in total loans $-4.5 \%$ in 2017, which is close to the French indicator of $3.7 \%$. This level remained acceptable in Germany and France during the study period. In Ukraine, since 2013, the share of unsecured loans has been growing at a very fast rate.

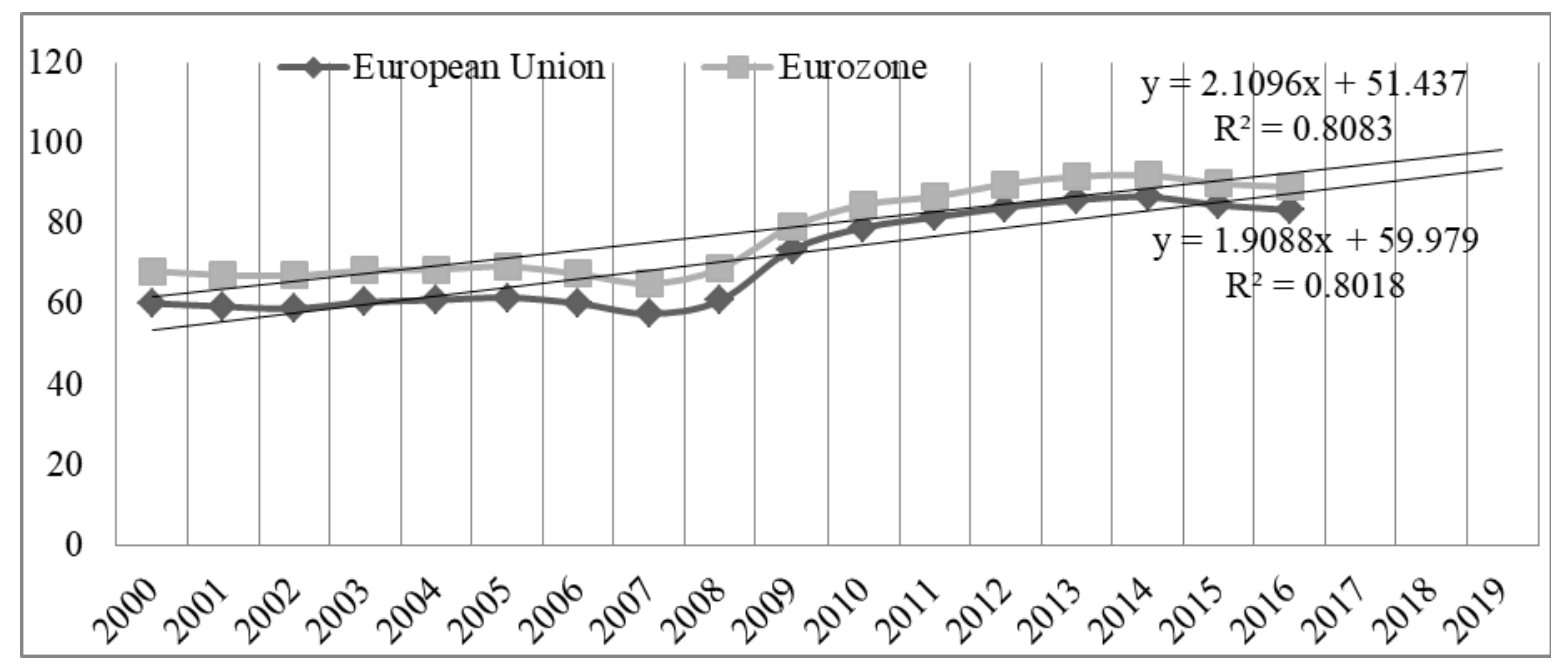

Fig. 2. General government debt ( \% of GDP) [6]

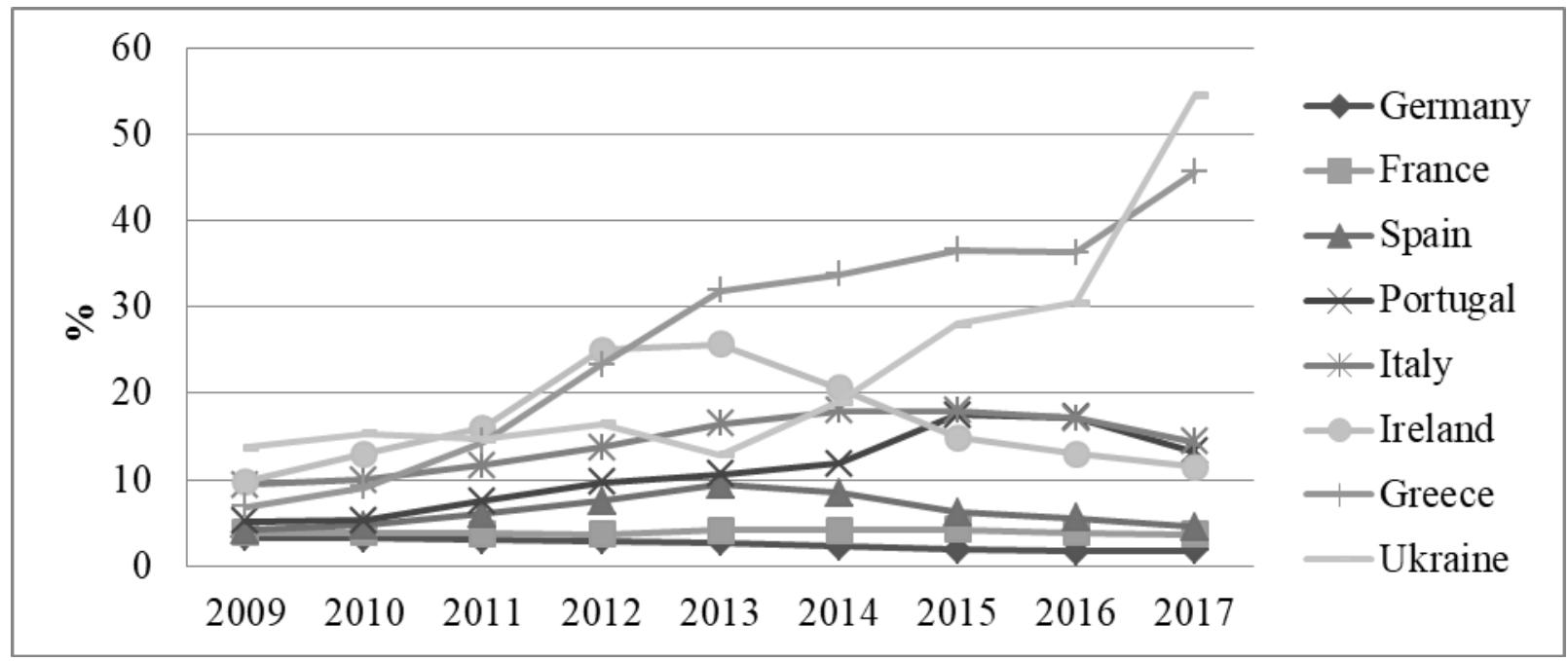

Fig. 3. Ratio of unsecured bank loans to their total number in some EU countries and Ukraine (\%) [23]

The Figure 4 shows the dynamic of the long-term government bonds profitability of the EU countries. It was the highest in the study period in Greece. If the profitability of France's government bonds declined from 3.25 to $0.3 \%$ between 2009 and 2016, during the same period, similar Greek government bonds were offered with profitability of $5-25 \%$, that indicates a loss of investors' interest and attempts by the Greek government to raise funds for financing the state budget deficit, which in 2009 was more than 
$15 \%$. The profitability of government bonds in Ireland in 2009-2011was increasing, the government urgently attracted funds to finance the state budget deficit, which was $12-32 \%$ during this period (instead of the criterion within $3 \%$ ). Then profitability was gradually decreasing. Similar measures for raising funds through government bonds were also carried out by the Portuguese government, and profitability rates were also significant. The state budget deficit in Italy was not as significant as in the reviewed countries but government debt servicing forced the government to increase the profitability on government bonds since 2012, which in turn led to even more debt growth.

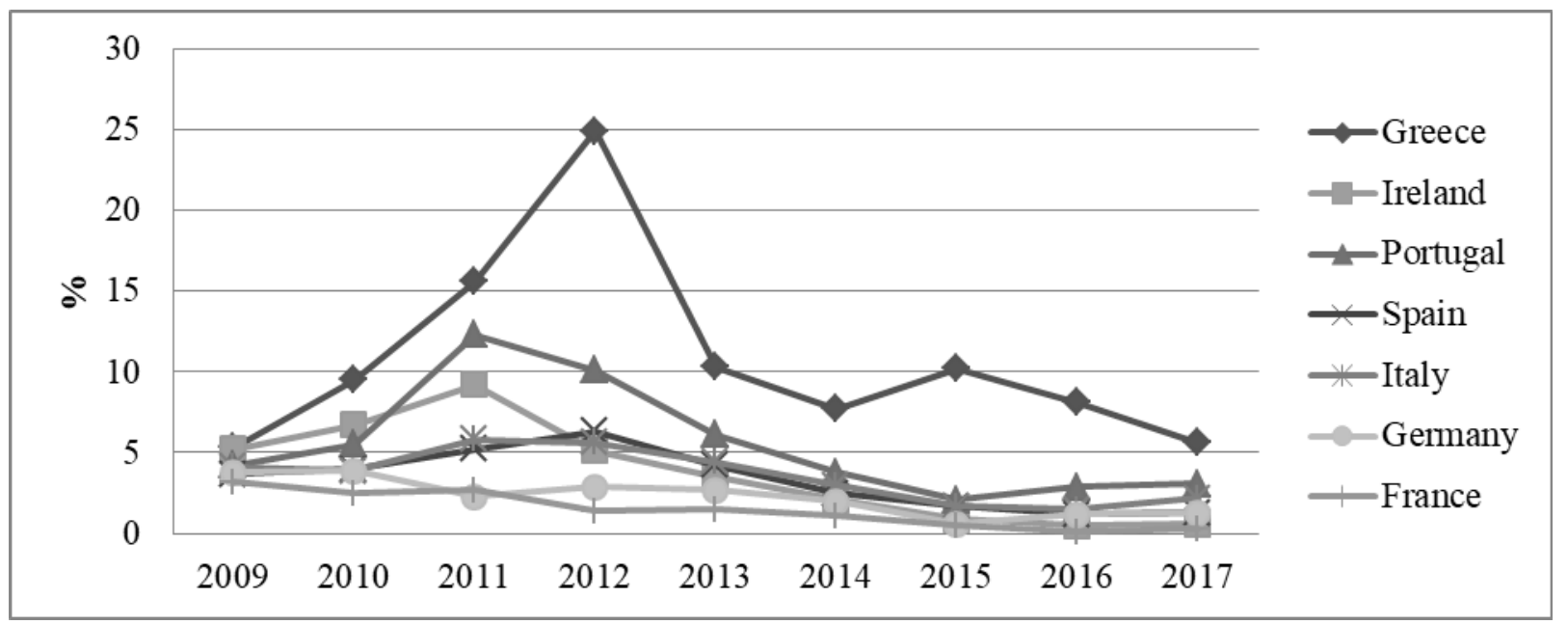

Fig. 4. Dynamics of the average government bond yields of some EU countries (\%) [7]

In 2002 and 2003, the Federal Republic of Germany and France, which were among the founders of the European Union, first broke the public debt criterion (Figure 5). The ratio of public debt to the GDP of Greece and Italy significantly exceeded the criteria of the Maastricht Treaty for the entire study period. In Ireland, Spain and Portugal, the index had been increasing until 2014, since 2015 there has been a gradual decline, but the ratio in Portugal and Spain is still very high. And only Ireland is approaching the limit of $68 \%$.

In Ukraine, the state of the debt sphere has features of a chronic crisis, which was exacerbated by, in particular, the financial and economic losses of Ukraine from the annexation of the Crimea by the Russian Federation and military actions in the Donbass. In 2014-2016, there was a tendency of increasing the level of public debt to GDP of Ukraine. However, by the end of 2017, this indicator had fallen for the first time since 2011 and had become closer to the $60 \%$ determined by the Maastricht Treaty. However, the ratio remains at a dangerous level, Ukraine is a part of a group of countries with high debt load and a significant negative balance of payments.

In a study Lajtkepová, the results of the correlation analysis concluded that there is «moderate agreement between the ranking of indebtedness and share of social benefits in GDP, and between indebtedness and unemployment rate. The ranking of countries by economic level is only very weakly correlated with the ranking of countries by indebtedness" [10]. To determine the combined effect of the ratio of unsecured banks loans and long-term government bond yields of the countries on their state debt level we have calculated the multiple correlation coefficient.

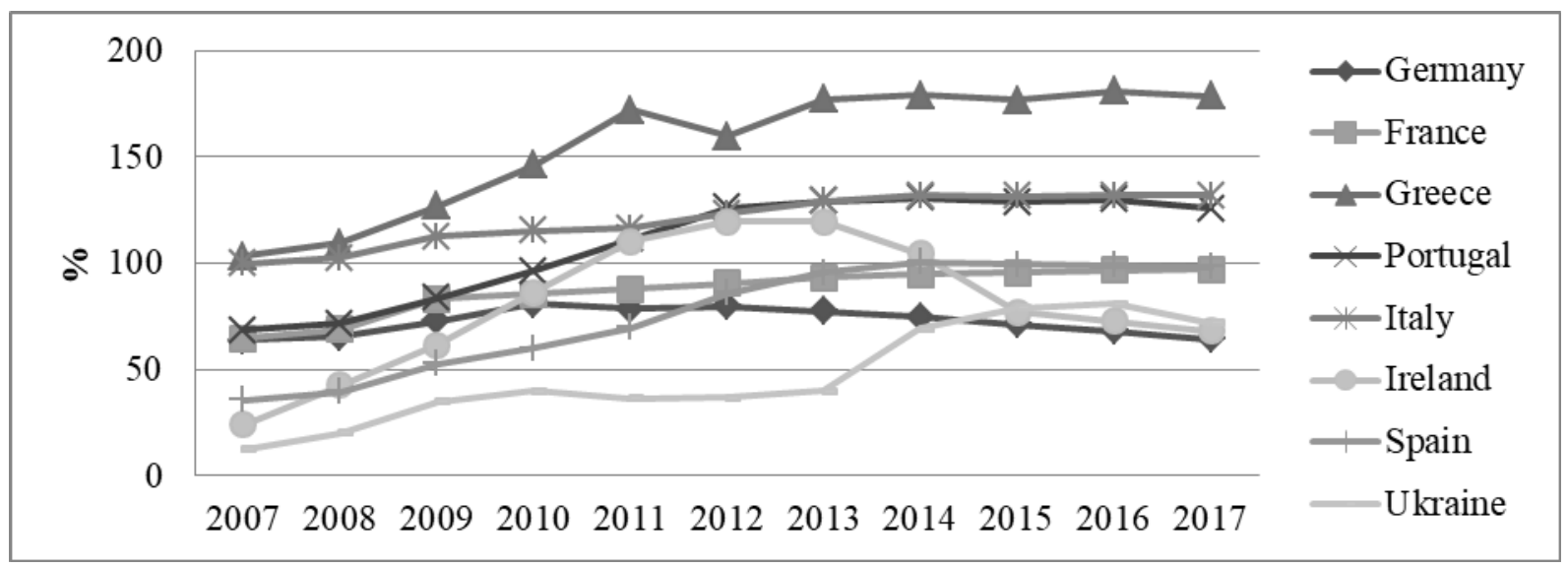

Fig. 5. The government debt of some EU countries and Ukraine (\% of GDP) [6; 15] 
As a result, the following data was obtained: coefficient of multiple correlation is $\mathrm{R}=0.86$ for Greece, $\mathrm{R}=0.98$ for Ireland, $\mathrm{R}=0.70$ for Portugal, $\mathrm{R}=0.90$ for Spain and $\mathrm{R}=0.96$ for Italy. This means that the cumulative impact of the two abovementioned factors on the investigated countries' public debt is significant for all countries, but the lowest $-70 \%$ is in Portugal and the highest - 98\% in Ireland. The coefficient of multiple correlation is $\mathrm{R}=0.81$ for Germany and $\mathrm{R}=0.96$ for France, which means that the combined effect of the two abovementioned factors is significant and is $81 \%$ and $96 \%$ respectively. For Ukraine, the result of the calculation showed $\mathrm{R}=0.70$, which means that the studied indicators show a sufficiently high level of relation.

That means that a significant amount of high-risk loans that threatens the banking sector and a rise in the profitability of government bonds for supporting investment interest had a direct connection with the public debt of the EU and Ukraine. This confirms the existing economic concept. There is no reason in order for the state debt should have decrease during the economic downturn. When the monthly payment of a portion of the debt is appropriate, the government does not cut expenditures or raise taxes to provide the funds required. Rather, it refinances the debt by selling new bonds and using the proceeds to pay holders of the maturing bonds. The new bonds are in strong demand because lenders can obtain higher interest return [13].

Also, a correlation analysis was carried out, the results of which allowed to assess the volume of state budget revenue effect on such indicators of the country's financial system function such as: the state budget spending, state surplus, public debt. The calculations were made for the EU countries (Germany, France, Greece, Ireland, Portugal, Spain and Italy) and Ukraine, Table 1 and Figure 6.

Table 1

An assessment of the relationship between the main components of the functioning of the financial system of some EU countries and Ukraine

\begin{tabular}{|c|c|c|c|c|c|c|c|c|}
\hline & 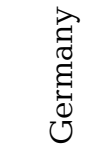 & 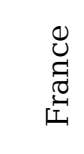 & $\begin{array}{l}\circlearrowright \\
\circlearrowright \\
\circlearrowright \\
\circlearrowright\end{array}$ & 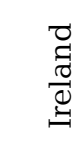 & 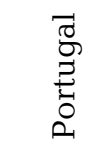 & 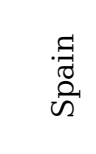 & 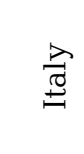 & 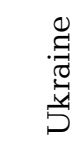 \\
\hline $\begin{array}{l}\text { State budget revenues / state } \\
\text { budget expenditures }\end{array}$ & -0.14 & 0.53 & 0.19 & 0.59 & 0.11 & -0.50 & 0.69 & 0.40 \\
\hline $\begin{array}{l}\text { State budget revenues / state } \\
\text { surplus }\end{array}$ & 0.55 & 0.47 & 0.61 & -0.31 & 0.538 & 0.78 & 0.14 & -0.67 \\
\hline State budget revenues / state debt & -0.11 & 0.84 & 0.87 & 0.01 & 0.79 & 0.17 & 0.83 & 0.48 \\
\hline
\end{tabular}

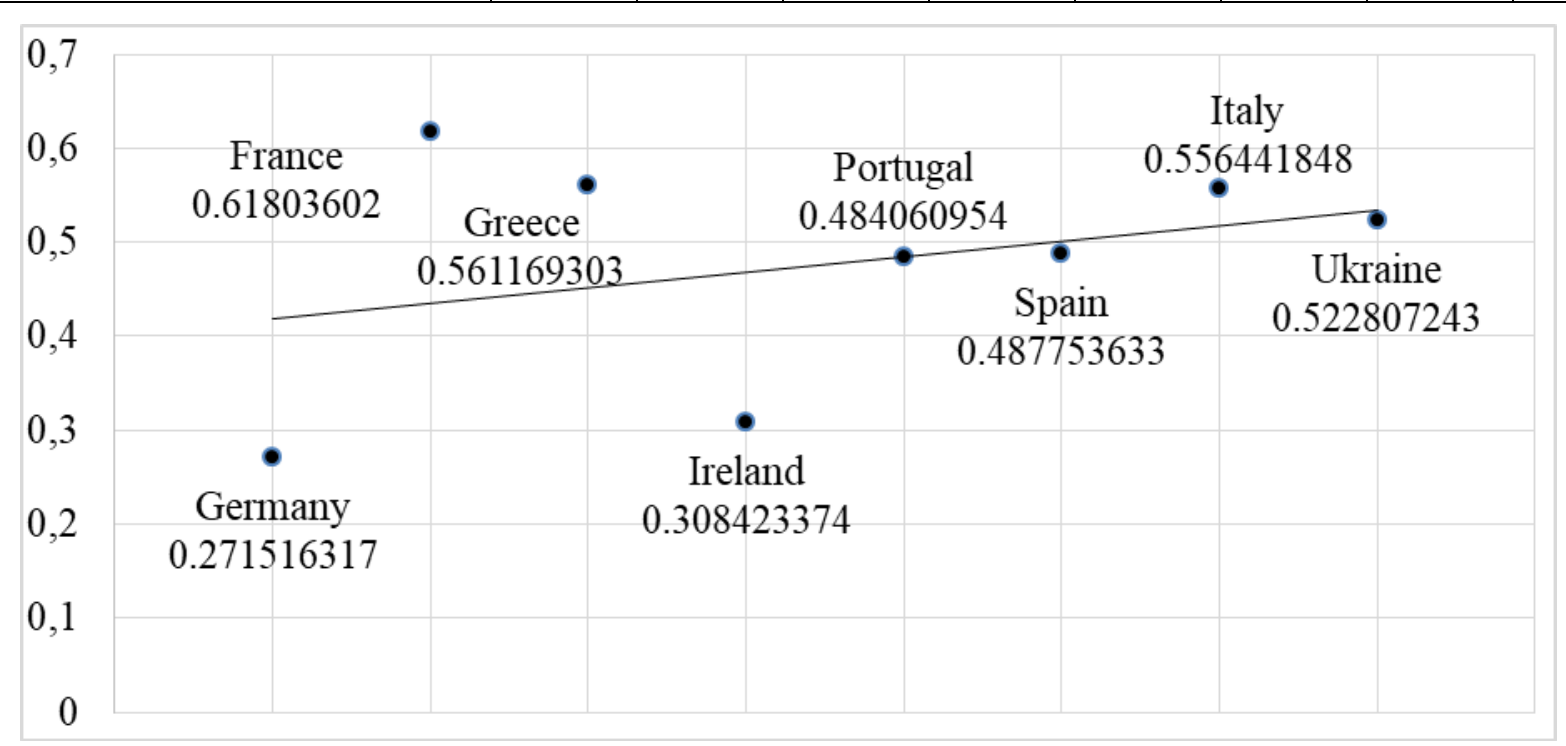

Fig. 6. Degree of relation of financial systems of some EU countries and Ukraine from the revenue part of the state budget

The results indicate the following:

1. For most of the countries studied (France, Greece, Portugal, Italy), there is a direct strong relation between the revenues of the state budget and the volume of public debt. It can also be noted that there is a correlation between the state budget revenues and the state surplus in Spain, between the revenues of the state budget and the state budget spending in Italy.

2. Analyzing the obtained data in general, it can be noted that for all the countries studied, the greatest correlation exists between the state budget revenues and the volume of public debt (the average value of the correlation coefficient is equal to 0.5 ). 
3. It should be noted that Spain is characterized by a significant inverse effect of the state budget revenues on the state budget spending, and in Ukraine significant inverse is observed between the revenues of the state budget and the state surplus.

4. In Germany and Ireland there is no correlation between the components of the financial system function. For other studied countries, a significant relation between the components is distinctive.

Taking into account the fact that the financial systems of the PIIGS countries, which had rather different levels of development and stability, were at the epicenter of the debt crisis, which negatively affected all the EU countries, without exception, in 2007 it was decided to radically strengthen supervision of financial sector. The result should be a gradual transformation of the financial systems of the EU countries, in which more stringent regulation rules will be applied, and the risks will appear at an early stage.

The main directions of the transformation of the modern European financial system in the context of the debt crisis are presented in Table 2 .

Table 2

The main directions of the transformation of the European financial system [3]

\begin{tabular}{|c|c|c|}
\hline $\begin{array}{l}\text { Direction of the } \\
\text { transformation }\end{array}$ & Year & Main point \\
\hline $\begin{array}{l}\text { Creation of new } \\
\text { control systems for } \\
\text { financial institutions }\end{array}$ & 2010 & $\begin{array}{l}\text { The European System of Financial Supervision (ESFS) has been introduced, } \\
\text { which includes the European Systemic Risk Board (ESRB) and three } \\
\text { European Supervisory Authorities (ESAs), namely: The European Banking } \\
\text { Authority (EBA); The European Securities and Markets Authority (ESMA); } \\
\text { The European Insurance and Occupational Pensions Authority (EIOPA) [5] }\end{array}$ \\
\hline $\begin{array}{l}\text { Creation of The } \\
\text { European Stability } \\
\text { Mechanism (ESM) }\end{array}$ & 2012 & $\begin{array}{l}\text { It is the successor of the EFSF (as a successor to the European Financial } \\
\text { Stability Facility EFSF). It was created as an international financial } \\
\text { institution by state-members of the euro zone. It provides emergency loans, } \\
\text { but instead, countries must carry out reform programs [22]. } \\
\text { In recent years, the European Parliament has been considering several } \\
\text { options for reforming the ESM. One of the key ideas is to transform ESM } \\
\text { into 'European Monetary Fund'[25] }\end{array}$ \\
\hline $\begin{array}{l}\text { Formation sof } \\
\text { supranational system } \\
\text { of banking's } \\
\text { institutions regulation }\end{array}$ & $\begin{array}{l}2009 \\
2009 \\
2012\end{array}$ & $\begin{array}{l}\text { - The Single Rulebook was created. It aims to provide a single set of } \\
\text { harmonized prudential rules which institutions through out the EU must } \\
\text { respect. This will ensure uniform application of Basel } 3 \text { in all Member States } \\
\text { [20]; } \\
\text { - Large-scale stress tests (EU-wide Stress Tests) are being implemented to } \\
\text { ensure the stable functioning of financial systems; } \\
\text { - A decision was made to establish a European Banking Union to support the } \\
\text { stability and unity of the banking sector in the Eurozone and the EU. } \\
\text { However, since the agreement on the creation, all stages have not yet been } \\
\text { completed, that predicting a large-scale banking reform (the creation of the } \\
\text { Single Supervisory Mechanism, the Single Resolution Mechanism and the } \\
\text { introduction of the European Deposit Insurance Scheme [22]); } \\
\text { - The European Union adopted a legislative package to strengthen the } \\
\text { regulation of the banking sector and to implement the Basel } 3 \text { agreement in } \\
\text { the EU legal framework [22]; } \\
\text { - The proposals of the European Commission to solve the problem of "too big } \\
\text { banks" by the EU regulatory authorities, in particular by the European } \\
\text { Commission (Too big to fail - TBTF), have been developed: structural } \\
\text { changes predicting reducing the risk of instability, reducing the risk of } \\
\text { banks becoming TBTF [19]; } \\
\text { - Asset quality rating program started (Asset quality Review): the ECB } \\
\text { estimates the banks and, according to its results, provides a list of banks that } \\
\text { are fall under rehabilitation. }\end{array}$ \\
\hline $\begin{array}{lr}\text { Increasing } & \text { of } \\
\text { integration } & \text { of } \\
\text { settlement } & \text { and } \\
\text { clearing sector } & \end{array}$ & 2008 & $\begin{array}{l}\text { - The beginning of the project T2S (TARGET-2 Securities), which is one of } \\
\text { the largest infrastructure projects that were started Eurosystem. }\end{array}$ \\
\hline
\end{tabular}




\begin{tabular}{|l|l|l|}
\hline $\begin{array}{c}\text { Direction of the } \\
\text { transformation }\end{array}$ & Year & \multicolumn{1}{c|}{ Main point } \\
\hline $\begin{array}{l}\text { Formation of a } \\
\text { common regulatory } \\
\text { program in the EU }\end{array}$ & 2012 & $\begin{array}{l}\text { - Adoption of an order on derivatives in the unorganized market, central } \\
\text { counterparties (SSR) and trade repositories (EMIR); } \\
\text { - Adoption of an order on central securities depositories (SDD). }\end{array}$ \\
\hline $\begin{array}{l}\text { Improving the } \\
\text { security, transparency } \\
\text { and efficiency of } \\
\text { financial markets }\end{array}$ & 2011 & $\begin{array}{l}\text { - «The European Commission adopted a legislative proposal for the revision } \\
\text { of MiFID (Directive on Markets in Financial Instruments) which took the } \\
\text { form of a revised Directive and a new Regulation. After more than two years } \\
\text { of debate, the Directive on Markets in Financial Instruments repealing } \\
\text { Directive 2004/39/EC and the Regulation on Markets in Financial } \\
\text { Instruments, commonly referred to as MiFID II and MiFIR, were adopted by } \\
\text { the European Parliament and the Council of the European Union» [21]. They } \\
\text { were published in the EU Official Journal in 2014 and were applied in 2018. }\end{array}$ \\
\hline
\end{tabular}

One of the key measures of the EU countries financial systems transformation is institutional reforming, which could correct the shortcomings which complicated the process and delayed the resolution of the Eurozone crisis in 2008, and prevent similar deep crises in the future. But at the same time, the creation of powerful institutions of the Eurozone will promote the formation of a nucleus of closely integrated member states. The President of the French Republic E. Macron repeatedly proposed the creation of a separate budget and its own Eurozone parliament, as well as the post of Minister of Finance and Economics of the EU. However, the Federal Chancellor of the Federal Republic of Germany, A. Merkel, supported the logic of small steps, which is also typical for the Netherlands and for the Northern Europe states because of Germany's growing financial obligations to finance the debts of other countries. However, the Franco-German compromise was reached and its boundaries are outlined in the Meseberg Declaration. Germany and France have agreed to create a single Eurozone budget since 2021, but it has not been decided how it will be filled (regular transfers from individual countries or financial transactions tax), questions about its size and purpose. It is expected that the budget will be used to strengthen economic convergence in the euro zone, which was almost disrupted due to a debt crisis [25].

The priority direction of the EU countries financial systems transformation is the formation of a sustainable financial system. Sustainable growth is one of the greatest challenges of the 21st century, as the UN Sustainable Development Goals evidenced [26]. As in previous structural transformations, the financial system will play one of the most important roles in this process: the full potential of the financial system should be used as a tool for the world economy's transition to sustainable development.

The European Commission believes that reaching the goals of the EU 2030 Strategy for smart, sustainable and inclusive economic growth will require about 2 trillion euro. The scale of the investment challenge gave a new view at the strategic role and regulation of the EU financial system. In this context, the establishment of a sustainable financial system can help to restore the economy by allocating capital to new industries, as well as increasing the efficiency of the capital mediation process by upgrading risk management, improvement of information flows and adjustment of key areas with long-term social goals [24].

Experts point out five key priorities for modeling a sustainable financial system in the EU, the so-called " $5 \mathrm{R}$ of Sustainable Finance" (Capital Reallocation and Raising, Risk, Responsibility, Reporting, Strategic Reset). A central challenge to finance sustainable development in the EU is the redistribution of capital [27]. Improving the risk management framework, clarifying the main responsibilities of financial institutions and upgrading reporting and disclosure of information through these aspects will be necessary for the full disclosure of sustainable funding flows.

This approach involves activating the entire financial system for providing sustainable development, both public finance institutions (government bodies) and commercial financial intermediaries, mobilizing public funds to invest in long-term economic growth goals. In order to continue to work effectively in this direction, in 2016 the European Commission set up an expert group on issues of sustainable financing and to prepare a roadmap for a stable financial system [24].

Until recently, the EU's efforts to promote sustainable financing have focused mainly on public finance through the European Investment Bank and the EU budget. Such an approach has added value with the start of the EU recovery plan after the financial crisis: it is expected that at least $40 \%$ of the European Investment Fund will be directed towards projects contributing to the objectives of the Paris Accord in the fight against climate change [28]. At the same time, sustainability factors have also been included in EU financial regulation, in particular with regard to corporate disclosure and pension regulation. In addition, there is a growing interest in incorporating the sustainable development dimension into the EU Capital Markets Union, which seeks to find new ways to mobilize funding for infrastructure both for small and medium-sized enterprises, for example, with the use of innovative technologies.

With regard to other perspectives of the financial systems transformation of the European Union, they can include the following:

-Continuing the trend towards integration of financial systems of individual EU member states; 
-Strengthening the influence of supranational bodies:

- Unification of financial infrastructure;

- Continuing integration of control over financial market sectors: banking, insurance and securities markets;

- Extending the powers of supranational supervisory authorities to maximize transparency and improve the quality of information relating to the financial activity of market participants and ensure the unity of prudential supervision practices in the EU;

- Harmonization of the principles of fiscal policy implementation in the EU member states, etc.

Thus, today one of the main drivers of the transformation of the financial systems transformation of the EU is the need to build a sustainable financial system that will be able to produce financial services taking into account socio-environmental factors and provide efficient financing for the needs of sustainable development. One of the most important characteristics of the process of transformation of the EU financial system is that it is being reformed on the basis of the principle of delegating the authorities to supranational institutions and other relevant organizations, both from national states and from the EU regulating institutions.

The study attempts, based on the results of calculations of authors, to use the European experience of transforming financial systems to find ways to create a financial system capable of confronting crises and ensuring sustainable economic development of Ukraine.

\section{Ensuring the transparency and reboot of the financial system includes:}

$\square$ removing insolvent banks from the market;

$\sqcup$ expanding the list of mandatory disclosure information, banks disclosing their financial and prudential reporting;

$\square$ transition to FINREP / COREP standards and the unified digital reporting standard;

$\square$ conducting the stress-testing of banks in accordance with the recommendations of the Basel Committee on Banking Supervision, the Council for Financial Stability, the Council on European Banking Supervision;

$\square$ legislative and technological support for the reformation of the stock exchange infrastructure of capital markets in order to protect the interests of investors through the gradual introduction of standards for the functioning of the capital markets infrastructure. In particular, implementation of the requirements of MiFID II and MiFIR;

$\sqcap$ improving the clearing and settlement infrastrncture of capital markets through the gradual introduction of international standards for the functioning of the capital markets infrastructure, in particular the requirements of CSDR, EMIR, PFMI; introduction of consolidated transaction reporting system unified for different classes of assets, taking into account requirements of EU acts, in particular MMSR, EMIR, SFTR, CSDR, REMIT;

$\square$ initiation of the process of creating a unified megacelator of the financial market on the basis of the Banking Supervision Department of the National Bank of Ukraine and the National Commission performing state regulation in the ficld of financial scrvices markets

\section{Ensuring sustainable development includes:}

$\Pi$ harmonization of banking regulations with Basel recommendations and FU directives;

$\square$ the introduction of an effective method of banking supervision on the basis of risks, in accordance with the rules of the ECB;

$\square$ taking measures at the national level to include sustainability in the strategy of the financial system;

$\square$ the correspondence of lending and financing of the banking sector with the goals of sustainable development;

$\square$ financial inclusion.

Fig. 7. The main directions of transformation of the financial system of Ukraine [3]

The adoption of EU experience is carried out in all segments of the financial sector. In order to make effective use of the experience of financial systems transformation of the EU countries and in order to create a financial system capable of ensuring sustainable economic development based on the development of a fully-fledged market competitive environment in accordance with the EU standards, in 2015, a Complex Program for the Development of the Financial Sector of Ukraine was elaborated and supplemented in 2018 by 2020 (Resolution of the Board of the National Bank of Ukraine dated June 18, 2015, No. 391 (as amended by the decision of the Board of the National Bank of Ukraine of May 31, 
2018 № 304)). Transformation efficiency will be achieved through complex changes in financial sector regulators and participants in the financial sector (different forms of ownership) (Figure 7).

\section{Conclusions.}

Summarizing the existing measures aimed at transforming the financial systems of the EU countries, it was concluded that they are conducted simultaneously in the following directions:

1) the creation of fundamentally new control systems for the activities of financial institutions;

2) a large-scale banking reform, in which the banking sector continues to comply with the requirements of Basel 3, as well as measures to expand the functions of the banking union are taken. Measures related to the banking sector include, for example, the introduction of three new leverage ratios and two liquidity ratios, as well as strengthening the requirements for banks' equity; conducting largescale stress tests (EU-wide Stress Tests); solving the problem of "too big banks" (Too big to fail) and others;

3) unification of the common regulatory platform (derivatives on the unorganized market, depositary, clearing and settlement activities, etc.).

The purpose of the financial systems transformation of the EU countries, within which the further unification of national financial systems takes place, is to build a financial system that supports the sustainable development of the economy of all EU countries. That is why the experience of European countries can be used and is already used to find ways to create a financial system capable of ensuring sustainable economic development of Ukraine. In particular, further approximation of regulation of the banking sector to the requirements of Basel 3, as well as with the requirements of the Regulations for The Financial Instruments Markets, called MiFID II and MiFIR, are provided for. It seems reasonable to phase out the implementation of international standards for the functioning of the capital markets infrastructure, in particular the requirements of CSDR, EMIR, PFMI; implementation of reporting standards FINREP, COREP; introduction of annual stress testing of banks. In addition, it is worth considering the possibility of initiating the process of creating a single mega regulator of the financial market. Based on the conducted analysis, it can be concluded that there is a need to further adaptation of the European experience of transformation of financial systems under Ukrainian realities. Looking ahead, a key question is to understand the main obstacles to the formation of a sustainable financial system in Ukraine and ways to overcome them.

\section{ВИКОРИСТАННЯ ДОСВІДУ ЄС З ТРАНСФОРМАЦІЇ ФІНАНСОВОЇ СИСТЕМИ У КОНТЕКСТІ БОРГОВОЇ КРИЗИ ДЛЯ УКРАЇНИ}

Шуба Марина Володимирівна, канд. екон. наук, доцент, Харківський національний університет імені В. Н. Каразіна, м. Свободи, 6, м. Харків, Україна, 61022, e-mail: marinashuba@karazin.ua; ORCID: orcid.org/0000-0003-2581-6914

Дерід Ірина Олександрівна, канд. екон. наук, доцент, Харківський національний університет імені В. Н. Каразіна, м. Свободи, 6, м. Харків, Україна, 61022, e-mail: i.a.derid@karazin.ua; ORCID: orcid.org/0000-0002-1593-3132

Ханова Олена В'ячеславівна, канд. геогр. наук, доцент, Харківський національний університет імені В. Н. Каразіна, м. Свободи, 6, м. Харків, Україна, 61022, e-mail: e.v.khanova@karazin.ua; ORCID: orcid.org/0000-0002-0681-4860

Макарчук Катерина Олексіївна, канд. екон. наук, доцент, Харківський національний університет імені В. Н. Каразіна, м. Свободи, 6, м. Харків, Україна, 61022, e-mail: k.makarchuk.@karazin.ua; ORCID: orcid.org/0000-0002-7712-3071

Трансформація фінансових систем є надзвичайно важливим процесом, оскільки стабільність світової економіки залежить від їх адекватності, збалансованості та ефективності. Фінансові системи країн ЄС зазнали низку трансформацій, під час яких були створені нові механізми посилення економічного управління. Однак ще не всі проблеми вирішені. Боргова криза виявила наявні недоліки в структурі, тим самим спровокувавши необхідність зміцнення фінансової архітектури шляхом вирішення існуючих проблем, одночасно виявляючи та запобігаючи можливим майбутнім загрозам. Предметом дослідження є основні напрями трансформації європейської фінансової системи в умовах боргової кризи. Мета - узагальнити основні напрямки трансформації фінансових систем ЄС в умовах боргової кризи та визначити можливості їх застосування для України. Використовуються загальнонаукові методи, такі як системний аналіз, який дозволив збирати та систематизувати статистичні дані про країни ЄС та Україну для подальшого аналізу, кореляційний аналіз та тренд-аналіз, що дозволило визначити сукупний вплив незабезпечених банківських кредитів та прибутковості довгострокових державних облігацій країн ЄС та України на рівень їх державного боргу. Отримано наступні результати: кореляційний аналіз показує наявність зв'язку між незабезпеченими банківськими кредитами та прибутковістю довгострокових державних облігацій країн ЄС та України з рівнем їх державного боргу. Висновки: існує досить багато можливостей застосування досвіду ЄС щодо трансформації фрінансових систем для України. Одним із основних напрямів $є$ впровадження щорічних стрес-тестів банків; продовження наближення регулювання банківського сектору до вимог Базеля 3 та впровадження коефіцієнту покриття ліквідністю (LCR); ініціювання процесу створення єдиного мега-регулятора фінансового ринку.

Ключові слова: фрінансова система; перетворення; борг, боргова криза.

\section{ИСПОЛЬЗОВАНИЕ ОПЫТА ЕС ПО ТРАНСФОРМАЦИИ ФИНАНСОВОЙ СИСТЕМЫ В КОНТЕКСТЕ ДОЛГОВОГО КРИЗИСА ДЛЯ УКРАИНЫ}

Шуба Марина Владимировна, канд.экон.наук, доцент, Харьковский национальный университет имени В. Н. Каразина, площадь Свободы, 4, г. Харьков, Украина, 61022, e-mail: marinashuba@karazin.ua; ORCID: orcid.org/0000-0003-2581-6914

Дерид Ирина Александровна, канд.экон.наук, доцент, Харьковский национальный университет имени В. Н. Каразина, площадь Свободы, 4, г. Харьков, Украина, 61022, e-mail: i.a.derid@karazin.ua; ORCID: orcid.org/0000-0002-1593-3132

Ханова Елена Вячеславовна, канд.геогр.наук, доцент, Харьковский национальный университет имени В. Н. Каразина, площадь Свободы, 4, г. Харьков, Украина, 61022, e-mail: e.v.khanova@karazin.ua; ORCID: orcid.org/0000-0002-0681-4860 Макарчук Екатерина Алексеевна, канд.экон.наук, доцент, Харьковский национальный университет имени В. Н. Каразина, площадь Свободы, 4, г. Харьков, Украина, 61022, e-mail: k.makarchuk.@karazin.ua; ORCID: orcid.org/0000-0002-7712-3071

Трансформация финансовых систем является чрезвычайно важным процессом, поскольку стабильность мировой экономики зависит от их адекватности, сбалансированности и эффективности. Финансовые системы стран ЕС прошли ряд 
трансформаций, во время которых были созданы новые механизмы усиления экономического управления. Однако еще не все проблемы решены. Долговой кризис выявил имеющиеся недостатки в структуре, тем самым спровоцировав необходимость укрепления фринансовой архитектуры путем решения существующих проблем, одновременно выявляя и предотвращая возможные будущие угрозы. Предметом исследования являются основные направления трансформации европейской финансовой системы в условиях долгового кризиса. Цель - обобщить основные направления трансформации финансовых систем ЕС в условиях долгового кризиса и определить возможности их применения для Украины. Используются общенаучные методы, такие как системный анализ, который позволил собирать и систематизировать статистические данные о странах ЕС и Украину для дальнейшего анализа, корреляционный анализ и тренд-анализ, что позволило определить совокупное влияние необеспеченных банковских кредитов и доходности долгосрочных государственных облигаций стран ЕС и Украины на уровень их государственного долга. Получены следующие результаты: корреляционный анализ показывает наличие связи между необеспеченными банковскими кредитами и доходностью долгосрочных государственных облигаций стран ЕС и Украины с уровнем их государственного долга. Выводы: существует достаточно много возможностей применения опыта ЕС по трансформации финансовых систем для Украины. Одним из основных направлений является внедрение ежегодных стресстестов банков; продолжение приближения регулирования банковского сектора с требованиями Базеля 3 и внедрения коэффрициента покрытия ликвидностью (LCR); инициирование процесса создания единого мега-регулятора финансового рынка.

Ключевые слова: финансовая система; трансформация; долг, долговой кризис.

\section{References}

1. Allen, F., Bartiloro, L., \& Kowalewski, O. (2005). The financial system of the EU 25. WFIC Working Paper. doi:10.2139/ssrn.871454.

2. Babenko, V.A., Sidorov, V.I., Savin, R.S. (2018). Activities of international agroholdings in the world market of foreign investments: investigation of trends and factors of impact in current financing conditions. Technology audit and production reserves, № 4/4(42), pp. 18-24. doi: 10.15587/2312-8372.2018.141135

3. Davies, R., \& Studnicka, Z. (2018). The heterogeneous impact of Brexit: Early indications from the FTSE. European Economic Review, 110 (C). doi: 10.1016/j.euroecorev.2018.08.003.

4. Derid I., Khanova O., Makarchuk K., Shuba M. (2019) Transformation of the financial systems of the EU countries in the context of the debt crisis: experience for Ukraine. Contemporary issues in economy. Proceedings of the 10th International Conference on Applied Economics Contemporary Issues in Economy: Finance. Toruń, Poland. P. 31-44. doi: 10.24136/eep.proc.2019.2

5. European Central Bank. The Transformation of the European Financial System: Second ECB Central Banking

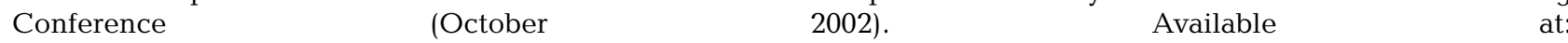
https://www.ecb.europa.eu/pub/pdf/other/transformationeuropeanfinancialsystemen.pdf?6e768151 ee38d21d95bc69 d456fe4f94.

6. European Commission (2018). The European system of financial supervision. Available at: https://ec.europa.eu/info/business-economy-euro/banking-and-finance/financial-supervision-and-risk-

management/european-system-financial-supervision_en.

7. Eurostat (2017). Statistics. Available at: https://ec.europa.eu/eurostat.

8. Fred Economic Data (2017). Long-Term Government Bond Yields: 10-year for: Germany, France, Greece, Ireland, Italy, Portugal, Spain. Available at: https://fred.stlouisfed.org/series/IRLTLT01DEM156N.

9. Hohlmeier, M., \& Fahrholz, C. (2018). The Impact of Brexit on Financial Markets - Taking Stock. International Journal of Financial Studies, 6 (3). doi:10.3390/ijfs6030065.

10. Kundera, J. (2013). Euro Crisis and the EMU Institutional Reforms. Equilibrium. Quarterly. Journal of Economics and Economic Policy, 8 (1). doi:10.12775/EQUIL.2013.001.

11. Lajtkepová, E. (2016). Differences and similarities in the indebtedness of EU member states after last financial crisis. Oeconomia Copernicana, 7 (4). doi:10.12775/OeC.2016.031

12. Llorent, J., Melgar, M., Ordaz, J., \& Guerrero, F. (2013). Stress Tests and Liquidity Crisis in the Banking System. Equilibrium. Quarterly Journal of Economics and Economic Policy, 8 (2). doi:10.12775/EQUIL.2013.012.

13. Maier, M. (2013). Potential Instruments That the ECB Could Take in Order to Face the Euro Zone Crisis. Equilibrium. Quarterly Journal of Economics and Economic Policy, 8 (1). doi.org/10.12775/EQUIL.2013.002.

14. McConnell,C. R., Brue, S. L., \& Flynn, S. M. (2009). Economics: Principles, Problems, and Policies. New York. McGraw-Hill/Irwin.

15. Miklaszewicz, S. (2016). Sovereign debt crisis of the Eurozone countries. Oeconomia Copernicana, 7 (3). doi:10.12775/OeC.2016.021.

16. Ministry of Finance of Ukraine (2017). Government debt. Available at: https://www.minfin.gov.ua/.

17. Mooslechner, P. (2004). The Transformation of the European Financial System. A Brief Introduction to Issues and Literature. OeNB Workshops, 1, 7-22.

18. Núñez-Ferrer, J., \& Rinaldi, D. (2016). The Impact of Brexit on the EU Budget: A Non-Catastrophic Event. CEPS Policy Brief, 347. Available at: papers.ssrn.com/sol3/papers.cfm?abstract_id $=2859407$.

19. Oesterreichische Nationalbank (May 2017). The financial system of the future. Available at: https://www.suerf.org/docx/r_ec1c59141046cd1866bbbcdfb6ae31d4_4657_suerf.pdf.

20. Perevozova I., Babenko V., Kondur O., Krykhovetska Z. and Daliak N. (2019). Financial support for the competitiveness of employees in the mining industry. SHS Web of Conferences, 65 (2019) Pp. 1-6. doi: https://doi.org/10.1051/shsconf/20196501001

21. Perevozova, I., Daliak, N., Babenko, V. (2019). Modeling of Financial Support for the Competitiveness of Employees in the Mining Industry. CEUR Workshop Proceedings, No. 2422, pp. 444-454. Available at: http://ceurws.org/Vol-2422/paper36.pdf 
22. Shuba, M. (2017). The unification of national banking systems regulation in the EU countries: experience for Ukraine. Economic Annals-XXI, 168 (11-12). doi: 10.21003/ea.V168-03.

23. The European Banking Authority (EBA) (2019). Available at: https://eba.europa.eu/regulation-andpolicy/single-rulebook.

24. The European Securities and Markets Authority (ESMA) (2018). MiFID II/MiFIR. Available at: https://www.esma.europa.eu/policy-rules/mifid-ii-and-mifir.

25. The European Stability Mechanism (2012). Available at: https://www.esm.europa.eu/aboutus/history \# context.

26. The World Bank (2017). Bank nonperforming loans to total gross loans. Available at: https://data.worldbank.org/indicator/FB.AST.NPER.ZS.

27. UNEP Inquiry (March 2016). Building a Sustainable Financial System in the European Union: the five 'R' s of market and policy innovation for the green transition. Available at: http://unepinquiry.org/wpcontent/uploads/2016/04/Building_a_Sustainable_Financial_System_in_the_European_Union.pdf.

28. Zoppè, A., \& Dias, C. (2019). The European Stability Mechanism: Main Features, Instruments and Accountability. Available at: http://www.europarl.europa.eu/RegData/etudes/BRIE/2014/497755/IPOLECON_NT(2014)497755_EN.pdf.

\section{Мітература}

1. Allen F., Bartiloro L., Kowalewski O. The financial system of the EU 25. WFIC Working Paper, 2005. doi:10.2139/ssrn.871454.

2. Babenko V.A., Sidorov V.I., Savin R.S. Activities of international agroholdings in the world market of foreign investments: investigation of trends and factors of impact in current financing conditions. Technology audit and production reserves. 2018. № 4/4(42). P. 18-24. doi: 10.15587/2312-8372.2018.141135

3. Davies R., Studnicka Z. The heterogeneous impact of Brexit: Early indications from the FTSE. European Economic Review. 2018. № 110. doi: 10.1016/j.euroecorev.2018.08.003.

4. Derid I., Khanova O., Makarchuk K., Shuba M. Transformation of the financial systems of the EU countries in the context of the debt crisis: experience for Ukraine. Contemporary issues in economy. Proceedings of the 10th International Conference on Applied Economics Contemporary Issues in Economy: Finance. Toruń, Poland, 2019. P. 31-44. DOI: 10.24136/eep.proc.2019.2

5. European Central Bank. The Transformation of the European Financial System: Second ECB Central Banking $\begin{array}{llll}\text { Conference } & \text { 2002). } & \text { Uctober }\end{array}$ https://www.ecb.europa.eu/pub/pdf/other/transformationeuropeanfinancialsystemen.pdf?6e768151ee38d21d95bc69 d456fe4f94.

6. European Commission. The European system of financial supervision. URL: https://ec.europa.eu/info/business-economy-euro/banking-and-finance/financial-supervision-and-risk-

management/european-system-financial-supervision_en.

7. Eurostat. Statistics. URL: https://ec.europa.eu/eurostat.

8. Fred Economic Data. Long-Term Government Bond Yields: 10-year for: Germany, France, Greece, Ireland, Italy, Portugal, Spain. URL: https://fred.stlouisfed.org/series/IRLTLT01DEM156N.

9. Hohlmeier M., Fahrholz C. The Impact of Brexit on Financial Markets - Taking Stock. International Journal of Financial Studies. 2018. № 6 (3). doi:10.3390/ijfs6030065.

10. Kundera J. Euro Crisis and the EMU Institutional Reforms. Equilibrium. Quarterly. Journal of Economics and Economic Policy. 2013. № 8 (1). doi:10.12775/EQUIL.2013.001.

11. Lajtkepová E. Differences and similarities in the indebtedness of EU member states after last financial crisis. Oeconomia Copernicana. 2017. № 7 (4). doi:10.12775/OeC.2016.031

12. Llorent J., Melgar M., Ordaz J., Guerrero F. Stress Tests and Liquidity Crisis in the Banking System. Equilibrium. Quarterly Journal of Economics and Economic Policy. 2013. № 8 (2). doi:10.12775/EQUIL.2013.012.

13. Maier M. Potential Instruments That the ECB Could Take in Order to Face the Euro Zone Crisis. Equilibrium. Quarterly Journal of Economics and Economic Policy. 2013. 8 (1). doi.org/10.12775/EQUIL.2013.002.

14. McConnell C. R., Brue S. L., Flynn S. M. Economics: Principles, Problems, and Policies. New York. McGrawHill/Irwin, 2009.

15. Miklaszewicz S. Sovereign debt crisis of the Eurozone countries. Oeconomia Copernicana, 2016 . № 7 (3). doi:10.12775/OeC.2016.021.

16. Ministry of Finance of Ukraine. Government debt. URL: https://www.minfin.gov.ua/.

17. Mooslechner P. The Transformation of the European Financial System. A Brief Introduction to Issues and Literature. OeNB Workshops. 2004. № 1. Pp. 7-22.

18. Núñez-Ferrer, J., \& Rinaldi, D. The Impact of Brexit on the EU Budget: A Non-Catastrophic Event. CEPS Policy Brief, 347. URL: papers.ssrn.com/sol3/papers.cfm?abstract_id $=2859407$.

19. Oesterreichische Nationalbank. The financial system of the future. URL: https://www.suerf.org/docx/r_ec1c59141046cd1866bbbcdfb6ae31d4_4657_suerf.pdf.

20. Perevozova I., Babenko V., Kondur O., Krykhovetska Z. and Daliak N. Financial support for the competitiveness of employees in the mining industry. SHS Web of Conferences. 2019, 65, pp. 1-6. doi: https://doi.org/10.1051/shsconf/20196501001

21. Perevozova, I., Daliak, N., Babenko, V. Modeling of Financial Support for the Competitiveness of Employees in the Mining Industry. CEUR Workshop Proceedings. 2019, No. 2422, pp. 444-454.

22. Shuba M. The unification of national banking systems regulation in the EU countries: experience for Ukraine. Economic Annals-XXI. 2017. № 168 (11-12). doi: 10.21003/ea.V168-03. 
23. The European Banking Authority (EBA). URL: https://eba.europa.eu/regulation-and-policy/single-rulebook. 24. The European Securities and Markets Authority (ESMA). MiFID II/MiFIR. URL: https://www.esma.europa.eu/policy-rules/mifid-ii-and-mifir.

25. The European Stability Mechanism. URL: https://www.esm.europa.eu/about-us/history \# context.

26. The World Bank. Bank nonperforming loans to total gross loans URL: https://data.worldbank.org/indicator/FB.AST.NPER.ZS.

27. UNEP Inquiry. Building a Sustainable Financial System in the European Union: the five 'R' $s$ of market and policy innovation for the green transition. URL: http://unepinquiry.org/wpcontent/uploads/2016/04/Building_a_Sustainable_Financial_System_in_the_European_Union.pdf.

28. Zoppè A., Dias C. The European Stability Mechanism: Main Features, Instruments and Accountability. URL: http://www.europarl.europa.eu/RegData/etudes/BRIE/2014/497755/IPOL-ECON_NT(2014)497755_EN.pdf. 